\title{
鉄とビスマス-亜鉛融液との反応
}

\author{
若松良德* 大西正已* 下齐敏唯** \\ *九州工業大学工学部物質工学科 \\ **九州工業大学機器分析センター
}

J. Japan Inst. Metals, Vol. 59, No. 3 (1995), pp. 277-283

\section{Reaction between Iron and Bismuth Zinc Melt}

\author{
Yoshinori Wakamatsu*, Masami Onishi* and Toshitada Shimozaki** \\ * Department of Materials Science and Engineering, Faculty of Engineering, Kyushu Institute of Technology, \\ Kitakyushu \\ ${ }^{* *}$ Center for Instrumental Analysis, Kyushu Institute of Technology, Kitakyushu
}

\begin{abstract}
Fe specimens were annealed in molten Bi containing 1-20 mass $\% \mathrm{Zn}$ at 553 to $673 \mathrm{~K}$, in order to investigate the structures of $\mathrm{Fe}-\mathrm{Zn}$ alloy layers formed by reactive diffusion between $\mathrm{Fe}$ and molten $\mathrm{Bi}-\mathrm{Zn}$. On surfaces of the specimens, seven kinds of alloy layers composed of the following Fe-Zn intermetallic phases were formed depending on the annealing condition: (1) $\Gamma$, (2) $\Gamma$ and $\Gamma_{1}$, (3) $\Gamma, \Gamma_{1}$ and $\delta_{1},(4) \Gamma, \Gamma_{1}, \delta_{1}$ and $\zeta,(5) \Gamma, \delta_{1}$ and $\zeta$, (6) $\delta_{1}$ and $\zeta$, and $(7) \zeta$. The structure of the alloy layer changed in order of $(1) \rightarrow(2) \rightarrow(3) \rightarrow(4),(1) \rightarrow(2) \rightarrow(3) \rightarrow(5)$ or $(1)$ $\rightarrow(3) \rightarrow(7)$ with increasing $\mathrm{Zn}$ content of molten $\mathrm{Bi}$ and in order of $(7) \rightarrow(6) \rightarrow(5) \rightarrow(4)$ with annealing time in molten $\mathrm{Bi}$ saturated with $\mathrm{Zn}$. It seems that the $\mathrm{Fe}-\mathrm{Zn}$ intermetallic phase having zinc activity approximately equal to that of molten $\mathrm{Bi}-\mathrm{Zn}$ is formed at an outer surface of the alloy layer and that the lag in the appearance of $\delta_{1}, \Gamma$ and $\Gamma_{1}$ phase layers in the molten Bi saturated with $\mathrm{Zn}$ is caused by the formation of $\zeta$ phase layer having a non-equilibrium composition ranging from the $\delta_{1}$ to $\zeta$ phases.

(Received July 28, 1994)
\end{abstract}

Keywords: iron, bismuth zinc melt, hot dipping, reactive diffusion, iron zinc alloy layer, intermetallic phase, formation process, growth kinetics

\section{I. 緒言}

合金化溶融亜鉛めっき皮膜は酎食性，塗装性叔よび溶接性に 優れているが，プレス加工すると鋼素地から娳離しやすい. 剝 離は素地に接した脆い $\Gamma$ 相の層内岁るいはその近傍を起点と して伝播し(1)-(3)，Г層の厚さが厚い性ど著しい(2)-(4)ので，め

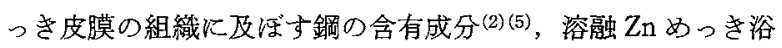
の $\mathrm{Al}$ 含有量 ${ }^{(6)(7)}$, 合金化温度 ${ }^{(8)}$ や時間 ${ }^{(6)(7)}$, 合金化後の冷却 速度(8)などの製造条件の影響が種々調べられてきた。しかし， 溶融 Zn わっき皮膜を加熱して合金化する方法を採用する限り， $\mathrm{Fe}$ 濃度の高い合金相の成長を阻止し得ない(9)-(11)ので， $\Gamma$ 層の 存在しないめっき皮膜を得ることが困難であるように考完られ る.

プレス加工性の良い合金化溶融 Zn めっき皮膜の製造法を開 発するには，Fe-Zn 合金層の形成反応関する基礎的な研究の 蓄積が必要であるとの観点から，著者らは先に ${ }^{(12)} \mathrm{Zn}$ を少量添 加した $\mathrm{Pb}$ 融液中に和ける $\mathrm{Fe} の$ 合金層形成反応を調べた。を の結果, $\mathrm{Zn}$ の融点以下の温度では Fe-Zn 拡散対(10)(13) と同様 の過程を経て Fe-Zn 合金相が逐次形成すること，また加熱条 件によっては $\Gamma$ 層の存在しない合金層が得られることを見出 した．しかし，Pb快融点が十分に低くないために，合金層形
成反応の初期過程までを明らかにする火は至らなかった。 本研究では，Bi西な $\mathrm{Fe}$ と反応しないことに着目して， $\mathrm{Bi}-\mathrm{Zn}$ 融液中に扣ける $\mathrm{Fe}$ の合金層形成反応を調べた. $\mathrm{Pb}-\mathrm{Zn}$ 融液では十分に明らかたするとのできなかった合金層形成反 応の初期過程や合金層の組織に及济す融液中の $\mathrm{Zn}$ 濃度の影響 などについて報告する。

\section{II. 実 験 方 法}

既報(12) と同じ化学組成を有する純度が 99.9 mass\%の冷間 压延鋼板（厚さ $2 \mathrm{~mm}$ )を $9 \mathrm{~mm} \times 9 \mathrm{~mm}$ の寸法に切断して鏡面 に仕上げた後，脱脂して $\mathrm{Fe}$ 試料とした。 $\mathrm{Bi}-\mathrm{Zn}$ 融液は純度が 99.999 mass\%の Bi 粒と 99.9 mass\%の Zn 片を用いて作製し， $\mathrm{Bi}$ の量を20〜25 g一定として Zn 添加量(添加後の Zn 濃度) を1〜20 mass\%の範囲で種々変えた．Bi- $\mathrm{Zn}$ 融夜の温度は $553 \sim 673 \mathrm{~K}, \mathrm{Fe}$ 試料の加熱時間は 3.6 176.4 ks の範囲とし, 加熱は既報 ${ }^{(12)}$ そ準じて内部を約 $5 \times 10^{-3} \mathrm{~Pa} の$ 真空にした内径 $14 \mathrm{~mm}$, 長さ $130 \sim 150 \mathrm{~mm}$ の石英カプセル中で行った.

加熱後の $\mathrm{Fe}$ 試料については, $9 \mathrm{~mm} \times 9 \mathrm{~mm}$ の面の中央を 垂直火切断し，断面に和ける合金層の組織と厚さを光学顕微鏡 で調べた．組織観察のための腐食液には $\mathrm{HNO}_{3}$ が 3 vol\%のナ イタール溶液を用い, 厚さは接眼マイクロメータで測定した。 
また，一部の試料については，合金層の断面て括ける Feの濃 度分布をEPMA で測定した. 測定は Fe $K \alpha$ 線について行い， $\mathrm{Fe}$ の質量分率 $M$ から純 $\mathrm{Fe} 100 \%$ とたときの Fe $K \alpha$ 線の 相対強度 $I$ を求める際には，既報(12) と同じ標準試料から得た 下式を用いた。

$$
\begin{gathered}
I=34.973 M^{3}-60.711 M^{2}+125.91 M-0.197 \\
\text { III. 実験結果および考察 }
\end{gathered}
$$

\section{1. 合金層の組織}

Fig. 1 は本実験で得られた合金層の断面に括ける典型的な 顕微鏡組織を示す。いずれす，下部が素地であり，中央の帯状

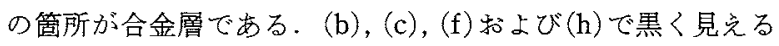
上部の箇所は試料の埋め込みに用いた樹脂であり，(b)と(c) を除く合金層の上部には Bi が存在している。これらのBi 試料を融液から取り出すときに付着したものであり，Bi 中に は凝固時に晶出したとみられる針状の $\mathrm{Zn}$ が存在している．縝 $\mathrm{Bi}$ 融液は純 $\mathrm{Fe}$ に対する好性が覀いので，(b)々(c)の合金層 にBiが付着していない理由については，扣そらく融夜中の $\mathrm{Zn}$ 濃度が低いため，また融液に接して形成された合金相の $\mathrm{Fe}$ 濃度が高いためであると考えられる。

Fig. 2 はFig. 1(a) と(b)飞示した $2 つ の$ 試料について，合 金層の断面に和ける Fe 濃度を素地から表面に向けて EPMA で線分析したときの結果である。素地部の線分析曲線を省略し た関係上，純 $\mathrm{Fe}$ を100\%とした相対強度で $\mathrm{Fe} K \alpha$ 線の強度を 示した. 図中の 4 組の破線は式(1)から求めた $\Gamma, \Gamma_{1}, \delta_{1} な ら$ びに 示す.これらとの比較から，曲線(b)すなわち Fig. 1(b)の合 金層は $\Gamma$ 単相で構成されているすのと見なし得る。曲線(b)で は Fe $K \alpha$ 線の相対強度が16 17\%付近ですクニックを生じて いるが，この箶所のクニックには再現性が認められなかった。

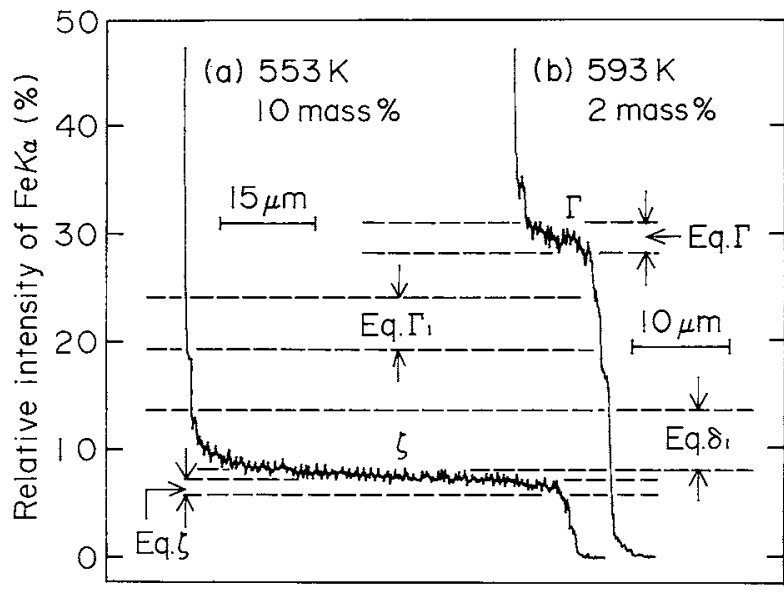

Distance

Fig. 2 EPMA line analysis for cross sections of the same specimens as shown in Fig. 1(a) and (b).

測定に用いたEPMA は電子ビームの半径执よびステージスキ ャンの最小ステップ幅がいずれも $0.5 \mu \mathrm{m}$ と大きいこと,さら に狭い領域を拉大して湘定したことがこのようなクニックを生 じた原因であると考学る。曲線(a)火見られるように，Fig． 1(a)の合金相は $\delta_{1}$ 相からら相までの幅広い組成範讲を有して いるが，この相はとである. Fe-Zn 桩散対の加熱初期炇相と して出現したら相 ${ }^{(13)}$ の場合も，Fig. 2(a) と注济同様の組成が 得られた。

Fig. 1(c) および(d) と同じ試料の断面をEPMAで線分析し たときの結果をそれぞれ Fig. 3(a)と（b)飞示す．曲線(a)の $\delta_{1}$ 相の平衡組成範围内と と相の平衡組成近傍ならびに曲線(b)の 相対強度が $37 \%$ 付近に見受けられるクニックは上述の EPMA
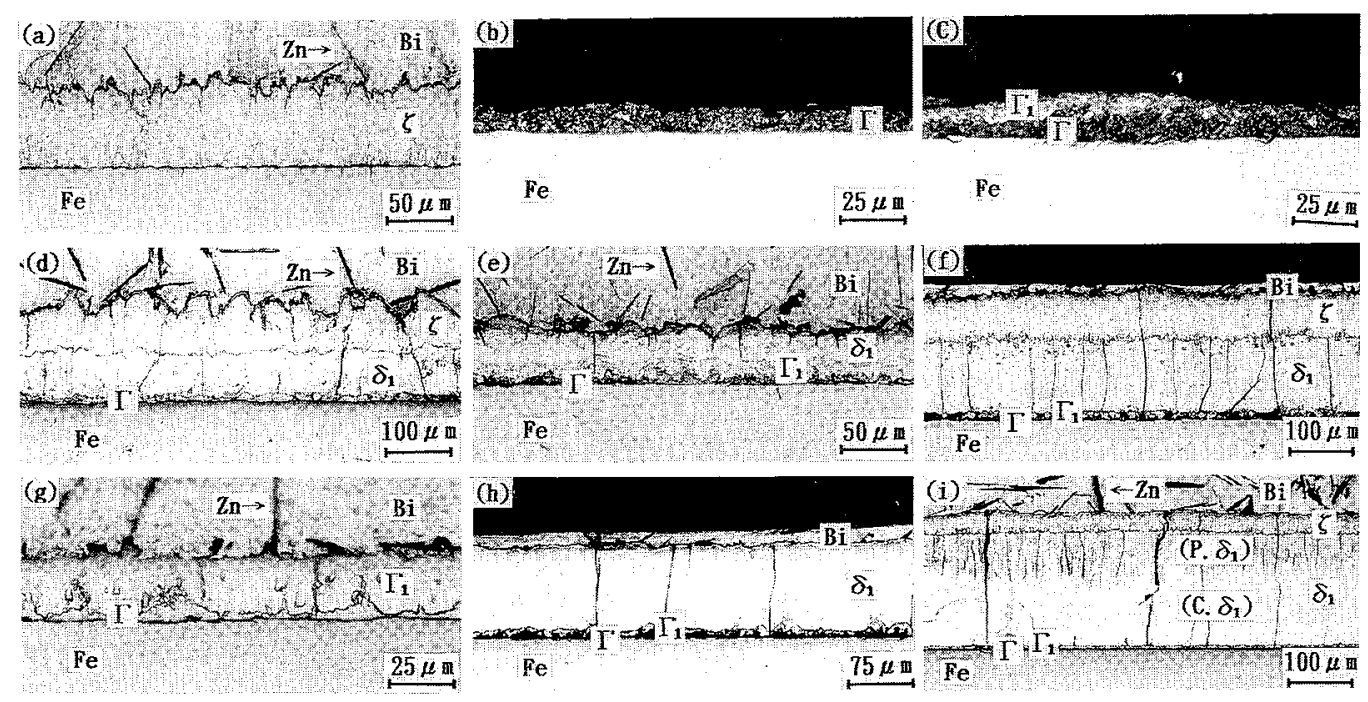

Fig. 1 Photomicrographs of cross sections of Fe specimens annealed in molten Bi containing various amounts of $\mathrm{Zn}$ for 90 ks at various temperatures.

(a) $553 \mathrm{~K}, 10$ mass\%; (b) $593 \mathrm{~K}, 2$ mass \%; (c) $593 \mathrm{~K}, 3$ mass\%; (d) $593 \mathrm{~K}, 10$ mass\%; (e) $633 \mathrm{~K}, 5$ mass\%; (f) $633 \mathrm{~K}$, 10 mass\%; (g) $673 \mathrm{~K}, 5$ mass\%; (h) $673 \mathrm{~K}, 7$ mass $\%$; (i) $673 \mathrm{~K}, 10$ mass $\%$. 
の性能上生じたものである.これらの線分析曲線との比較から， Fig. 1(c)の合金層は $\Gamma$ と $\Gamma_{1}$ の 2 相, 同じく(d)の合金層は $\Gamma$, $\delta_{1}$ 扣よび $っ$ の相で構成されていることがわかる.

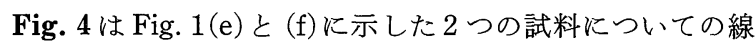
分析結果である.（f)の試料については， Fe 素地に接した，黒 く見える厚さが薄い層とその上の厚さが薄い，白く見える層の 両方を同時に判別でさるよらな結果が得られなかったので，線 分析曲線を 2 本示した. (b) は白い層，（c）は黒い層が検出さ れたときの結果であり，(c)については Fe 濃度の低い領域を 省略した。これらの結果から, Fig. 1(f)の合金層は $\Gamma, \Gamma_{1}, \delta_{1}$

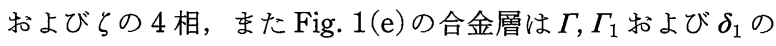
3 相で構成されていることがわかる.

Fig. 5 は加熱時間が $90 \mathrm{ks}$ のときの加熱温度 $T$ ならびに Bi 融液への $\mathrm{Zn}$ 添加量 $C_{\mathrm{Zn}}$ と形成した合金層の組織との関係を示 す. $\delta_{1}$ 相については, Fig. 1(i) に見受けられるよらに，組織 が palisade $\delta_{1}$ 之称される柵状層と compact $\delta_{1}$ と称される無地 層の 2 層となる場合があったので, 柵状層をP. $\delta_{1}$, 無地層を C. $\delta_{1}$ として示した. また，C. $\delta_{1}$ 層が出現しないときの $\delta_{1}$ 相は

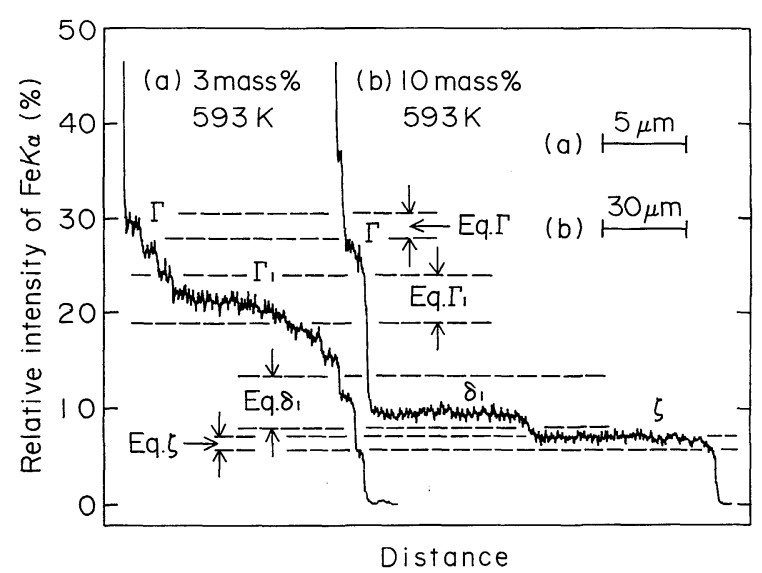

Fig. 3 EPMA line analysis for cross sections of the same specimens as shown in Fig. 1(c) and (d).

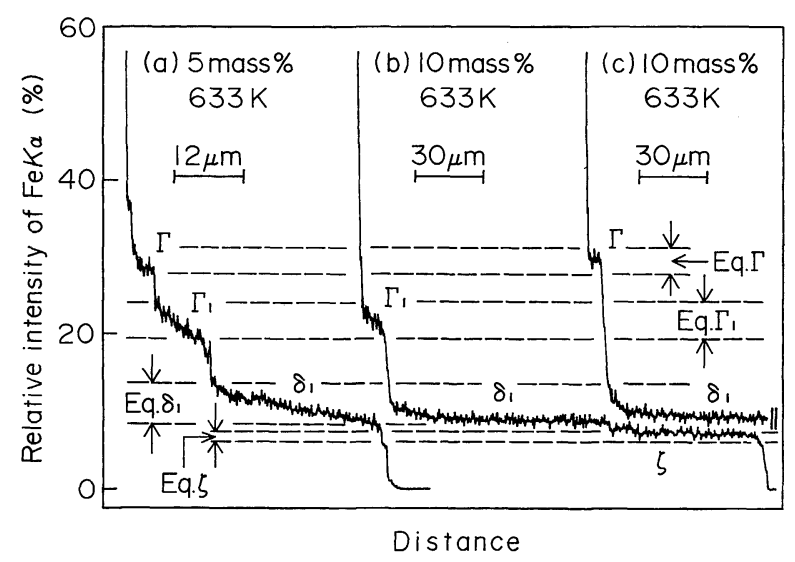

Fig. 4 EPMA line analysis for cross sections of the same specimens as shown in Fig. 1(e) and (f).

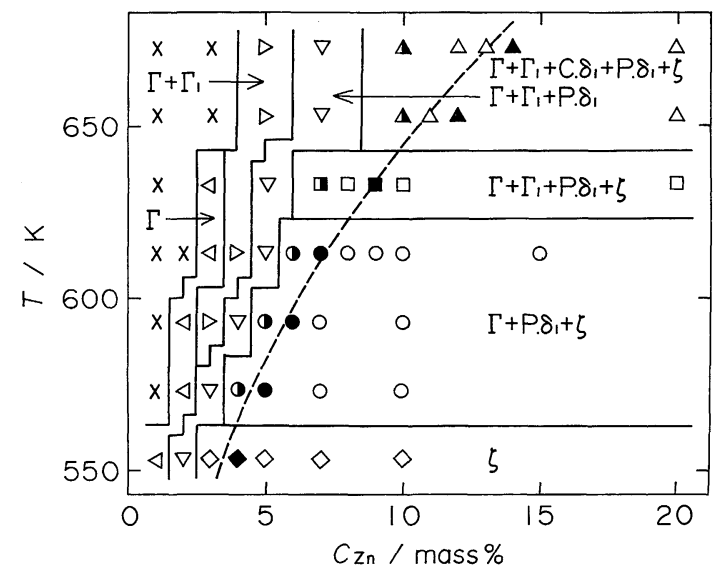

Fig. 5 Variation of microstructure of Fe- $\mathrm{Zn}$ alloy layer with annealing temperature $T$ and $\mathrm{Zn}$ content $C_{Z_{n}}$ of molten $\mathrm{Bi}$ for $\mathrm{Fe}$ specimens annealed for $90 \mathrm{ks}$.

柵状組織がかならずしも鮮明でない場合も見受けられたが，す べて P. $\delta_{1}$ とした. P. $\delta_{1}$ 層と C. $\delta_{1}$ 層については, 組織や化学的 性質が異なり, 両層の境界で微小硬度や濃度が急激に変化する ため，異種相であるとする見解(15)も存在するが，X線回折の 結果から同一相(16)(17)であると見なされている．図中の $\times$ 印は 合金層の形成が認められなかった範囲であり，破線は $\mathrm{Bi}$ 融液 中の $\mathrm{Zn}$ の溶解度曲線(18)である．これより，C. $\delta_{1}$ 層は Zn 添加

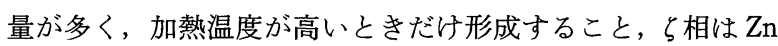
添加量が溶解度近くまで増加しないと形成されないこと, Zn 添加量の増加に伴って合金層の表面に拈ける形成相が $\mathrm{Fe}$ 濃度 の高い相から低い相に変わることがわかる.

\section{2. 形成相の厚さ}

Fig. 6 は 673 K, $90 \mathrm{ks}$ の加熱で形成した個々の合金相およ び合金層全体の厚さ $W$ と $\mathrm{Zn}$ 添加量 $C_{\mathrm{Zn}}$ との関係を示す． $\Gamma$ 相と $\Gamma_{1}$ 相については，ともに厚さが薄く，相境界が不規則に 波打っているために，それぞれを区別して測定することが困難 であったので，両相の合計厚さを示した． $\Gamma$ 相と $\Gamma_{1}$ 相の合計 厚さは他の合金相がまだ形成されていない $\mathrm{Zn}$ 添加量が 5 mass\%のときに最も厚く, $\mathrm{Zn}$ 添加量が 10 mass\%以上で P. $\delta_{1}$ 層とC. $\delta_{1}$ 層を合わせた $\delta_{1}$ 相全体の厚さが注ぼ一定になり， 14 mass\%以上では $\%$ 相拉よび合金層全体の厚さがほぼ一定に なっている.

Fig. 7 は加熱時間が $90 \mathrm{ks}$ のとき種々の温度におけるら相 の厚さ $W$ と $\mathrm{Zn}$ 添加量 $C_{\mathrm{Zn}}$ との関係を示す. $\mathrm{Zn}$ 添加量がある 値に達すると, ら相の厚さが一定になる傾向はすべての加熱温 度について認められ，その Zn 添加量の值は加熱温度が高いほ ど大きい. また，一定值に達したとさの厚さもらが単相として 形成される $553 \mathrm{~K}$ の場合を除くと, 高温ほど厚いことがわか る. Fig. 5 に示した全体を黒く塗りつぶした記号はら相の厚さ が一定になった Zn 添加量である. いずれも Bi 融液中の $\mathrm{Zn}$ の 溶解度と注汸一致しているので, それらの $\mathrm{Zn}$ 添加量でら相の 厚さが一定になったのは, それ以上 $\mathrm{Zn}$ 添加量を増やしても融 液中の $\mathrm{Zn}$ 濃度が変わらないためであると考えられる. 


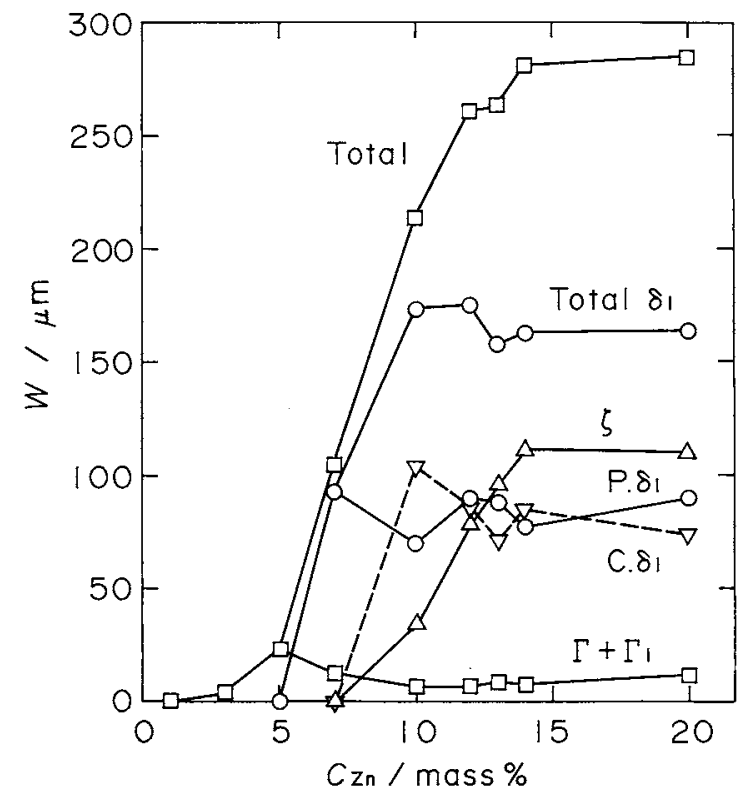

Fig. 6 Relationship between $\mathrm{Zn}$ content $C_{\mathrm{Z}_{\mathrm{n}}}$ of molten $\mathrm{Bi}$ and thickness $W$ of Fe- $\mathrm{Zn}$ intermetallic phase layers for $\mathrm{Fe}$ specimens annealed for $90 \mathrm{ks}$ at $673 \mathrm{~K}$.

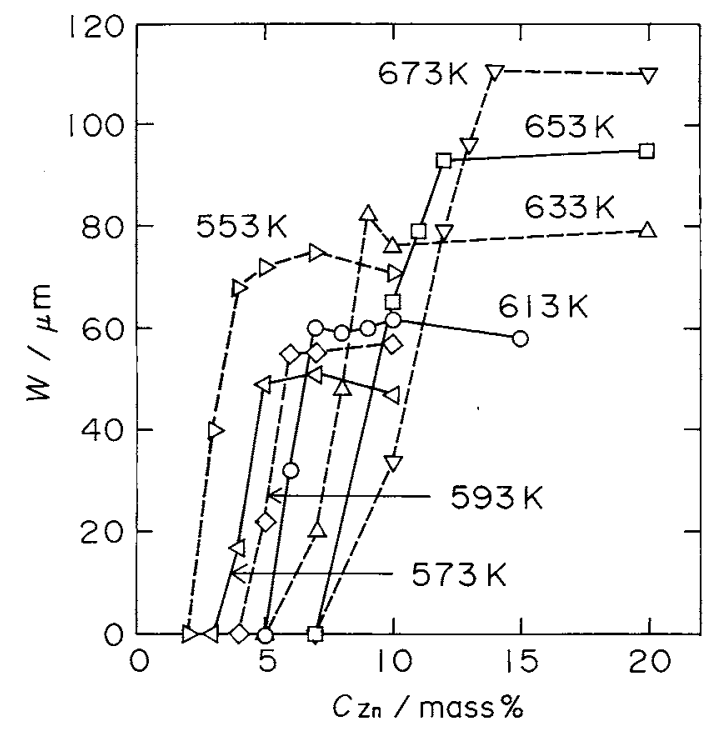

Fig. 7 Relationship between $\mathrm{Zn}$ content $C_{\mathrm{Zn}}$ of molten $\mathrm{Bi}$ and thickness $W$ of $\zeta$ phase layer for $\mathrm{Fe}$ specimens annealed for $90 \mathrm{ks}$ at various temperatures.

Fig. 8 は同じく加熱時間が $90 \mathrm{ks}$ のきの種々の温度にお ける $\delta_{1}$ 相全体の厚さ $W$ と $\mathrm{Zn}$ 添加量 $C_{\mathrm{Zn}}$ との関係を示す. $\delta_{1}$ 相についても，加熱温度が高い注ど，厚さが一定になるZn 添 加量の値が大きく，また一定値に達したときの厚さも厚い傾向 が認められる. Fig. 5 に示した半分黒く塗り潰した記号は $\boldsymbol{\delta}_{1}$ 相の厚さが一定になった Zn 添加量である．これより， $\delta_{1}$ 相の 厚さはその上に わかる.

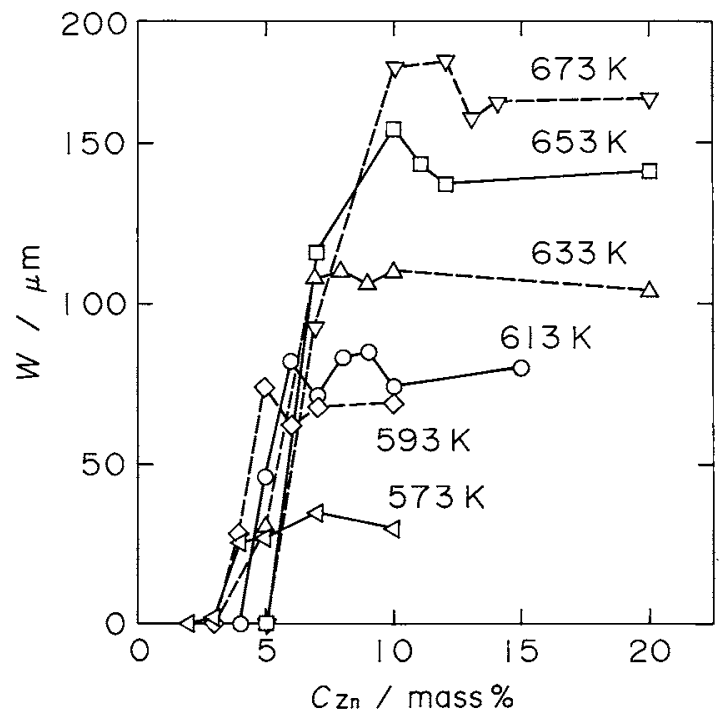

Fig. 8 Relationship between $\mathrm{Zn}$ content $C_{Z_{\mathrm{n}}}$ of molten $\mathrm{Bi}$ and thickness $W$ of $\delta_{1}$ phase layer for Fe specimens annealed for $90 \mathrm{ks}$ at various temperatures.

\section{3. $\mathrm{Zn}$ 添加量と合金層表面の形成相との関係}

Fig. 5 に示したように，Zn 添加量によって合金層の最表面 に形成される合金相が異なるので, 融液中のZnの活量と合金 層表面の形成相との関係を調べてみた。

Fig. 9 は $\mathrm{Zn}$ の活量 $a_{\mathrm{Zn}}$-組成 $C_{\mathrm{Zn}}$ 曲線を本実験の加熱温度に 抢社る Bi-Zn 融液(実線) と $673 \mathrm{~K} の \mathrm{Fe}-\mathrm{Zn}$ 系(破線) ${ }^{(19)}$ につい て示したものである. Bi-Zn 融夜の Znの活量酒ついては，加 熱温度に怙ける測定值が見当たらなかったので，純 Bi 融液中 での值を $0, Z n$ の溶解度に拈ける值を 1 として，その間を直線 近似した。それらの直線上の記号は合金層表面の形成相を示 し，例えば丸印は該当する加熱温度と $\mathrm{Zn}$ 添加量で表面に が形成したことを意味している．Fe- $\mathrm{Zn}$ 系の活量-組成曲線と の比較から，ら相が表面に形成されたときの Bi-Zn 融液の $\mathrm{Zn}$ の活量は，いずれもら相の $\mathrm{Zn}$ の活量の範团内にあることがわ かる. ら相と同様の結果は $\delta_{1}$ 相についても認められ，不完全 ではあるが， $\Gamma_{1}$ 相と $\Gamma$ 相についても認められる。したがって， 合金層の表面には $\mathrm{Bi}-\mathrm{Zn}$ 融液の $\mathrm{Zn}$ の活量に見合った $\mathrm{Fe}-\mathrm{Zn}$ 合 金相が形成された可能性が強い。

このよらな結果が得られた理由としては，Bi-Zn 融液と合金 層との界面では両者の間に泀ぽ平衡関係が成立しているためで あると考学られる.ちなみに，平衡関係が成立しているとき は，融液に接した Fe-Zn 合金相表面のZnの化学ポテンシャル $\mu_{\mathrm{Zn}}^{\mathrm{S}}$ が界面に括ける融液のそれ $\mu_{\mathrm{Zn}}^{\mathrm{L}}$ 上等しいので, 式 (2)に示 すように，両者の標準化学ポテンシャル $\mu_{\mathrm{Zn}}^{\circ}$ と $\mu^{\circ} \mathrm{Z}_{\mathrm{n}}$ が等しい と仮定すれば，式( 3 )と(4)から式(5)が得られる.

$$
\begin{aligned}
& \mu_{\mathrm{Zn}}^{\circ}=\mu^{\circ} \mathrm{Zn}_{\mathrm{Zn}}^{\mathrm{L}} \\
& \mu_{\mathrm{Zn}}^{\mathrm{S}}=\mu^{\circ} \mathrm{S}_{\mathrm{Zn}}^{\mathrm{S}}+\mathrm{R} T \ln a_{\mathrm{Zn}}^{\mathrm{S}} \\
& \mu_{\mathrm{Zn}}^{\mathrm{L}}=\mu^{\circ} \mathrm{L}_{\mathrm{Zn}}^{\mathrm{L}}+\mathrm{R} T \ln a_{\mathrm{Zn}}^{\mathrm{L}} \\
& a_{\mathrm{Zn}}^{\mathrm{S}}=a_{\mathrm{Zn}}^{\mathrm{L}}
\end{aligned}
$$

ここで， $a_{\mathrm{Zn}}^{\mathrm{S}}$ および $a_{\mathrm{Zn}}^{\mathrm{L}}$ はそれぞれ界面に执ける Fe-Zn 合金相 


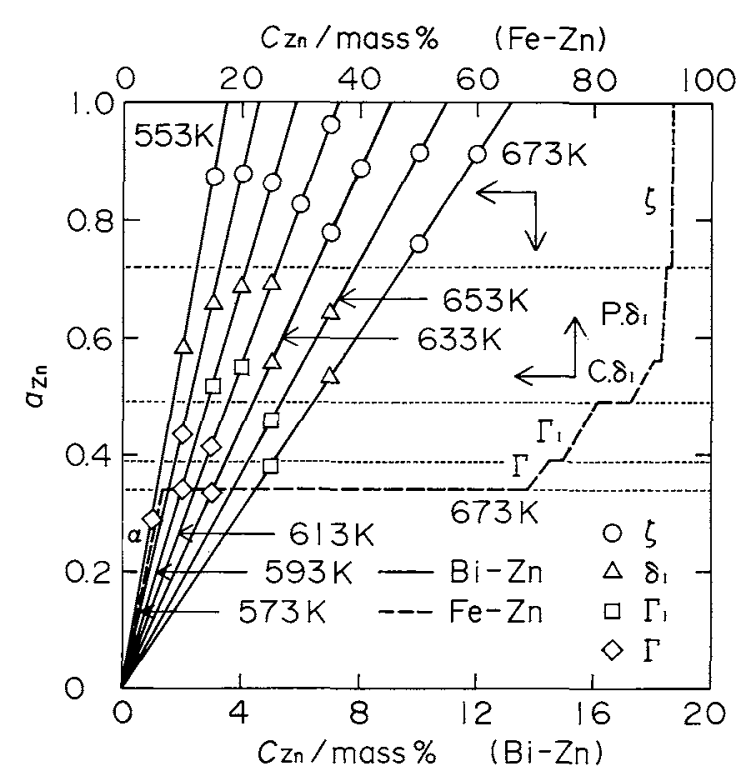

Fig. 9 Relationship between $Z n$ concentration $C_{Z \mathrm{n}}$ and activity $a_{\mathrm{Zn}}$ in molten $\mathrm{Bi}-\mathrm{Zn}$ at various temperatures compared with that in $\mathrm{Fe}-\mathrm{Zn}$ binary system at $673 \mathrm{~K}$. Various kinds of symbols on solid lines represent outermost phases of $\mathrm{Fe}-\mathrm{Zn}$ alloy layers formed on surfaces of $\mathrm{Fe}$ specimens in molten $\mathrm{Bi}-\mathrm{Zn}$.

抢よび $\mathrm{Bi}-\mathrm{Zn}$ 融夜の $\mathrm{Zn}$ の活量でする. 通常, $\mathrm{Zn}$ の融点以外 の温度では式 (2)が成立しないので, Bi- $Z n$ 融液と表面相との 間に平衡関係が成立しているとしても，本実験の加熱温度で式 (5)が成立しているとは語い難い，しかし， $a_{\mathrm{Zn}}^{\mathrm{S}}$ が $a_{\mathrm{Zn}}^{\mathrm{I}}$ に近い 值を有している可能性は十分考学られる。怙そらく，Bi-Zn 融 液の $\mathrm{Zn}$ の活量に見合った $\mathrm{Fe}-\mathrm{Zn}$ 合金相が合金層の最表面に形 成されたのは, $\mathrm{Bi}-\mathrm{Zn}$ 融夜と合金層との界面では, 両者の間に 注ば平衡関係が成立しているためである。

\section{4. 加熱温度と合金層の組織との関係}

Fig. 5 の溶解度曲線より右側の範用では，合金層の組織に $\mathrm{Zn}$ 添加量の影響が認められず，組織は加熱温度にの夕依存し ている.そこで，この範用に郝るる合金層の組織について，既 報(13)の Fe-Zn 拡散対の結果との比較を試みた. Fig. 10 は比 較結果を示し， $\mathrm{Fe}-\mathrm{Zn}$ 拡散対では加熱温度のみならず加熱時間 を変えて合金層の組織を調べたので，横軸には加熱時間の対数 をとり， $\mathrm{Pb}-\mathrm{Zn}$ 融液と $\mathrm{Fe}$ との反応で得られた結果 ${ }^{(12)}$ 火つい ても併記した。な拉， $\mathrm{Fe}-\mathrm{Zn}$ 拡散対拉よび $\mathrm{Pb}-\mathrm{Zn}$ 融液と $\mathrm{Fe}$ と の反応の結果炕ついては， $\Gamma_{1}$ 相が形成し始める温度と時間を

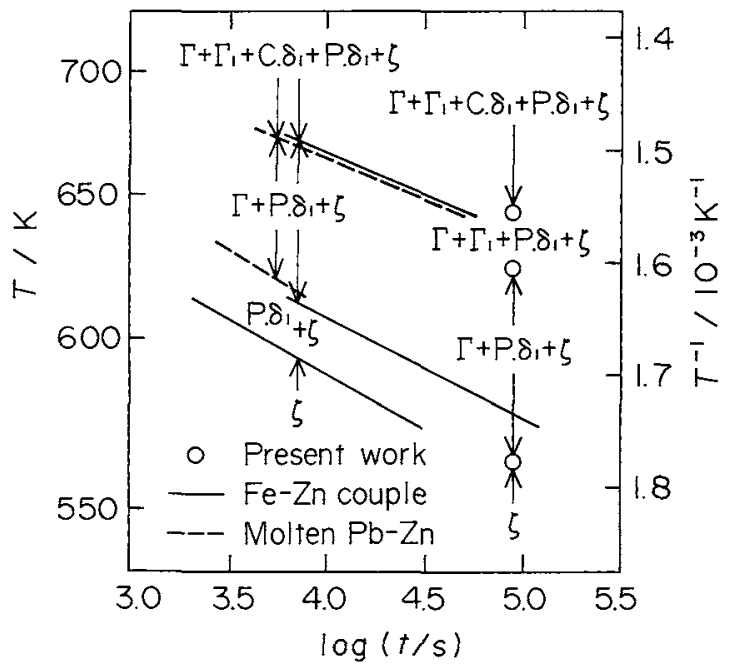

Fig. 10 Variation of microstructure of $\mathrm{Fe}-\mathrm{Zn}$ alloy layer with annealing temperature $T$ and time $t$. Results obtained from $\mathrm{Fe}$ specimens annealed in molten $\mathrm{Bi}$ containing 10 mass $\% \mathrm{Zn}$ for $90 \mathrm{ks}$ compared with those from $\mathrm{Fe}-\mathrm{Zn}$ diffusion couples and reaction of $\mathrm{Fe}$ with molten $\mathrm{Pb}$ containing 10 mass $\% \mathrm{Zn}$.

測定していないので， $\Gamma, \Gamma_{1}$, P.$\delta_{1}$ 誩よび $\zeta の 4$ 相から成る合金 層の範囲を $\Gamma, \mathrm{P} . \delta_{1}$ 特よび $\zeta の 3$ 相の範囲に含めて示した。 P. $\delta_{1}$ との 2 相から成る組織を除くと, 本実験に扣いて子 Fe$\mathrm{Zn}$ 拡散対の場合と同様の組織が得られ，それらの温度範曲に ついても，Fe- $\mathrm{Zn}$ 拡散対の結果とほぼ゙一致していることがわか る. Fe- $\mathrm{n}$ 拡散対の結果は加熱時間の経過に伴って合金相が逐 次形成し，高温汪ど相形成の潜伏期間が短いことを示している ので，本実験で得られた $Z \mathrm{n}$ 過飽和融液中に和ける合金層の組 織の温度依存性については，合金相の逐次形成現象之潜伏期間 の温度依存性に起因するすのと考光られる。

\section{5. 加熱時間と合金層の組織との関係}

P. $\delta_{1}$ との 2 相から成る組織が本実験で得られなかった理 由としては，その組織が得られる範囲から実験温度や時間が外 れていたためであると考劣られたので，加熱時間を種及変えて 合金層の組織を調べた。

Fig. 11 は Bi 融液への $\mathrm{Zn}$ 添加量を $\mathrm{Zn}$ の溶解度以上の 10 mass\%として $553 \mathrm{~K}$ で加熱したときの結果である. 加熱時間 が $14.4 \mathrm{ks} の$ (a)では, 形成したら相が円錐状を呈し，ら相の形 成されていない䇠所も見受けられる。このような組織が得られ たのは，加熱温度が低いためにら相の核形成が困難であったた
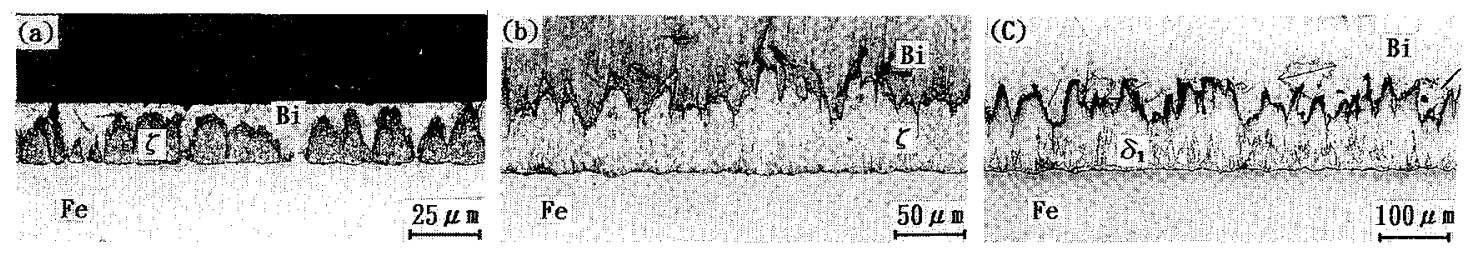

Fig. 11 Photomicrographs of cross sections of Fe specimens annealed in molten Bi containing 10 mass $\% \mathrm{Zn}$ at $553 \mathrm{~K}$ for various periods of time. (a) $14.4 \mathrm{ks}$, (b) $57.6 \mathrm{ks}$, (c) $176.4 \mathrm{ks}$. 
めであると考えられる．加熱時間が $57.6 \mathrm{ks}$ (b)では円錐状 晶が横方向に連なって層状化し， $176.4 \mathrm{ks}$ の(c)ではら層中に 粒状の $\delta_{1}$ 相が見受けられる. (c) と同様の組織は Fe-Zn 拡散 対の場合にも出現した. Fig. 2(a)に示したよらに, 単相とし て形成されたときの 衡な濃度を有しているので, 粒状 $\delta_{1}$ 相は $\mathrm{Fe}$ 素地と 層との 界面で形成されたものではなく，層の内部から直接析出した 可能性が強い. Fig. 5 の $\mathrm{Zn}$ 添加量が 2 mass\%のときの 553 Kの結果に見受けられるように，Zn 添加量が少ないために 相が形成されないときの合金層中には, Fig. 11(c)よりるかな り短い $90 \mathrm{ks}$ の加熱時間で $\delta_{1}$ 相のみならず $\Gamma_{1}$ 相と $\Gamma$ 相も形成 されている. したがって, Zn 過飽和融液中でこれらの相が潜 伏期間を経て形成されるのは, 非平衡な濃度を有する 成が原因であると考えられる。

Fig. 12 は Zn 添加量を同じく 10 mass\%として $593 \mathrm{~K} て ゙$ 種 々の時間加熱したときの結果である.この場合は加熱温度が高 いためか, Fig. 11(c) とほぼ同様の組織が $14.4 \mathrm{ks}$ の加熱で得

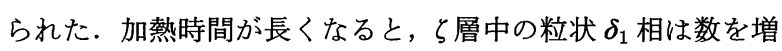
すとともに横方向に連なって層状化し，やがて 分断された. (b)はこの段階の組織を示している. (c) も 3 層 で合金層が構成されているが，Fe 素地に接した厚さの薄い， 黒く見える層は $\Gamma$ 相である.（b)の $\mathrm{Fe}$ 素地に接した 層を既 報(13) 従って $\zeta^{\prime}$ 層と称することにすると, $\zeta^{\prime}$ 層と $\mathrm{Fe}$ 素地と の間に $\Gamma$ 相がレンズ状に出現し，その後層状に成長するのに 伴って $\zeta^{\prime}$ 層は消失した. $\zeta^{\prime}$ 層の出現と消失の過程は既報 ${ }^{(13)}$ の $\mathrm{Fe}-\mathrm{Zn}$ 拡散対の場合とまったく同じであり, Fe- Zn 拡散対に拉 ける $\delta_{1}$ 相と $\Gamma$ 相も上記とまったく同様の過程を経て形成され た. $593 \mathrm{~K} て ゙ は$ 加熱温度が低いために， $\Gamma_{1}$ 相の形成過程まで を明らかにすることができなかったが， Bi- $\mathrm{Zn}$ 融液と Fe との 反応に怙いても Fe- $\mathrm{Zn}$ 拡散対の場合と同様に， $\zeta \rightarrow \delta_{1} \rightarrow \Gamma \rightarrow \Gamma_{1}$ の順に合金相が逐次形成されるものと考穴らる.

Fig. 13 は Zn 添加量を 10 mass\%として $613 \mathrm{~K} て ゙$ 加熱した ときの加熱時間の平方根と形成した合金相の厚さとの関係を示 す. 図中には, $613 \mathrm{~K}$ に抮ける Fe-Zn 拡散対 ${ }^{(13)}$ ならびに $\mathrm{Pb}$ $\mathrm{Zn}$ 融液と $\mathrm{Fe}$ との反応(12)で得られた結果も併記した。一点鎖 線で示した $t_{1}$ 㧊よび $t_{2}$ はそれぞれ Fe- $Z n$ 拡散対で得られた $P . \delta_{1}$ および $\Gamma$ 相の出現時間であり， $t_{3}$ は同じく P. $\delta_{1}$ 相の成長 速度が急増し始める時間である. 本実験に执いても， $t_{2}$ 付近で $\Gamma$ 相が形成し, $t_{3}$ 付近から P. $\delta_{1}$ 相の成長速度が増大し始めて いること，さらに層成長曲線自体が $\mathrm{Fe}-\mathrm{Zn}$ 拡散対の結果とほ ぼ一致していることがわかる. 合金相の形成過程のみならず成 長挙動についても， Fe- $Z n$ 拡散対の場合とほぼ同様の結果が得

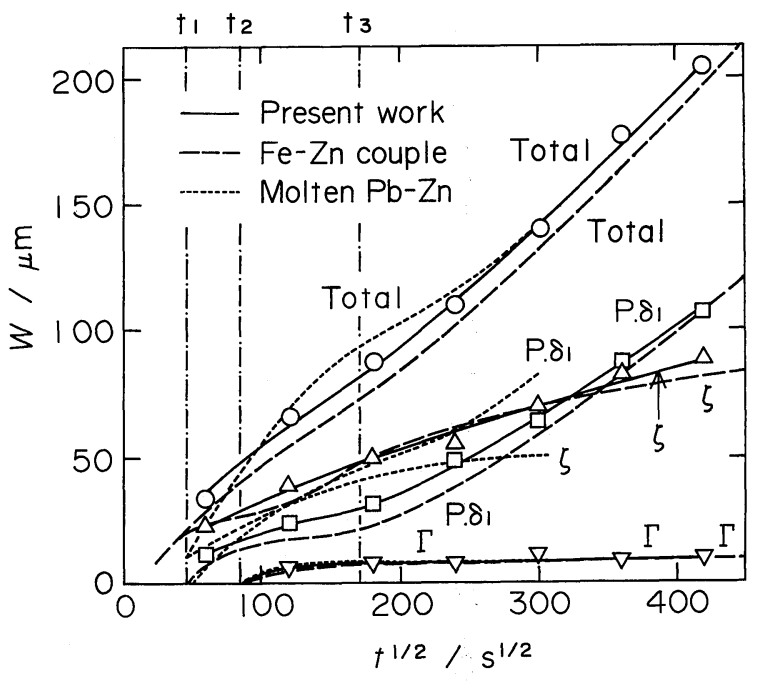

Fig. 13 Relationship between annealing time $t$ and thickness $W$ of $\mathrm{Fe}-\mathrm{Zn}$ intermetallic phase layers for $\mathrm{Fe}$ specimens annealed in molten $\mathrm{Bi}$ containing 10 mass $\% \mathrm{Zn}$ at $613 \mathrm{~K}$ compared with the results in Fe-Zn diffusion couples and reaction of $\mathrm{Fe}$ with molten $\mathrm{Pb}$ containing 10 mass $\% \mathrm{Zn}$ at $613 \mathrm{~K}$.

られたのは，Zn を過飽和に添加したときの Bi 融液は固体の純 $\mathrm{Zn}$ との間にほぼ平衡関係を有しているため, つまり $\mathrm{Zn}$ の化 学ポテンシャルが固体の純 $\mathrm{Zn}$ の值に近いためであると考壳 る.

\section{N. 結論}

Znを 1 20 mass\%添加した 553〜673 K の Bi 融液中で $\mathrm{Fe}$ 試料を加熱し，その表面に形成する Fe-Zn 合金層の組織，濃 度怙よび厚さを調べた，得られた結果は次の通りである。

（1）加熱後の $\mathrm{Fe}$ 試料表面には，(1) $\Gamma$ 相，(2) $\Gamma$ および $\Gamma_{1}$ 相, (3) $\Gamma, \Gamma_{1}$ お。よび $\delta_{1}$ 相, (4) $\Gamma, \Gamma_{1}, \delta_{1}$ おょび $\zeta$ 相, (5) $\Gamma, \delta_{1}$ お よび と相, (6) $\delta_{1}$ および 有する合金層が得られた.

(2) $\mathrm{Zn}$ 添加量の増加に伴って合金層の組織は(1) $\rightarrow(2) \rightarrow(3) \rightarrow$

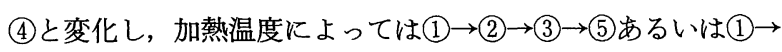
(3) $\rightarrow$ (7) と変化した. $Z n$ 添加量の増加に伴って合金層表面の形 成相が $\Gamma \rightarrow \Gamma_{1} \rightarrow \delta_{1} \rightarrow \zeta$ と変化するのは, 融液中の $\mathrm{Zn}$ の活量に 見合った Fe-Zn 合金相が表面に形成されるためである.

（3） $\mathrm{Zn}$ 過飽和融液中に括ける合金層の組織は加熱時間の経
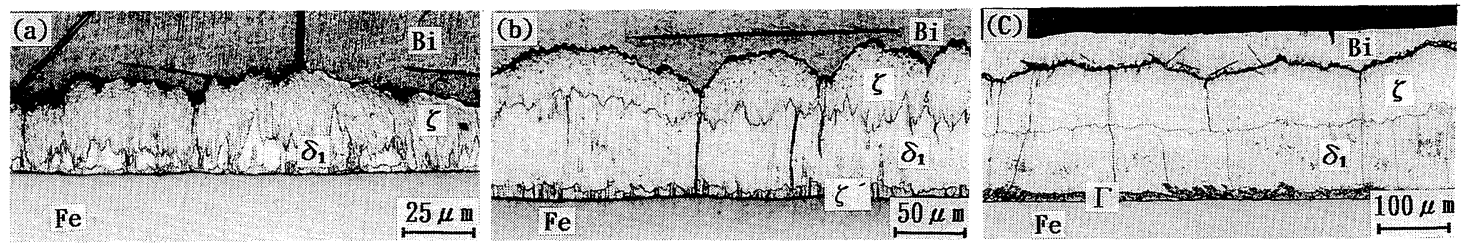

Fig. 12 Photomicrographs of cross sections of Fe specimens annealed in molten Bi containing 10 mass $\% \mathrm{Zn}$ at $593 \mathrm{~K}$ for various periods of time. (a) $14.4 \mathrm{ks}$, (b) $57.6 \mathrm{ks}$, (c) $176.4 \mathrm{ks}$. 
過炕伴って(7) $\rightarrow$ (6) $\rightarrow(5) \rightarrow(4)$ と変化した. $\zeta \rightarrow \delta_{1} \rightarrow \Gamma \rightarrow \Gamma_{1}$ の合金 相の形成順序は Fe-Zn 㹡散対の場合と全く同じであり，合金 相の成長挙動についても Fe-Zn 拡散対の場合と注添同様の結 果が得られた。この上うな結果が得られたのは，Zn過館和融 液中ではZnの化学ポテンシャルが固体の純 Znの值に近いた めである。

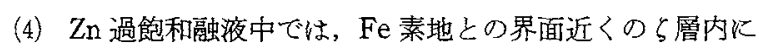

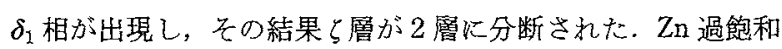
融液中で加熱時間の経過代伴って合金相が逐次形成するのは， 加熱初期飞単相として出現するら㑛が $\delta_{1}$ 相の平衡組成範用を も含む非平衡な濃度を有しているためである。

本研究の実験を遂行するに祭しては，元九州工業大学生， 野村雅樹氏(現在：新日鐵化学(姝)にご協力いただきました。同 氏のご劦力に対して感謝します。

\section{文献}

（1）中森俊夫, 圾根 正, 須藤忠三，嚙谷敦義：鉄と鋼， 77 (1991), 963.

（2）徳永良邦，山田正人，羽田隆司：鉄之鋼，72(1986)， 997.

（3）安田顯, 磯部誠, 飛山洋一, 大和康二：鉄と鋼,
$77(1991), 1184$.

（4）湏藤忠三，中森俊夫，西原 実：鉄と鋼，66(1980)，73.

(5)浦井正章, 有村光史, 赛裕音: 鉄飞鋼, 77(1991), 971.

（6）日户元，山崎桓友，森时短夫，矢部克彦，板東 誠志郎：鉄と鋼，70(1984), 1719.

(7) 浦井正章, 有村光史, 寺田誠, 山口雅彦, 堺裕彦, 野村伸吾：鉄と鋼， 77(1991)，971.

（8）櫻井理孝, 張力徫, 田尻泰久, 近藤隆明：鉄上鋼， $77(1991), 979$.

（9）大西正已，若松良德，佐及木輝憲，相良学：日本金属 学会誌, 36(1972), 1196 .

（10）大西正已，若松良徳，佐名木輝憲：日本金属学会誌。 37 (1973), 724.

(11) G. F. Bastin, F. J. J. van Loo and G. D. Rieck: Z Metallk., 65(1974), 656.

(12）若松良徳，桝本弘人，下睄敏唯，大西正已：鉃之鋼， 80 (1994), 231, N253.

(13) M. Onishi, Y. Wakamatsu and H. Miura: Trans. JIM, $15(1974), 331$.

(14) O. Kubaschewski: Iron-Binary Phase Diagrams, Springer-Verlag, Berlin, (1982), 172.

(15) M. A. Ghoniem and K. Löhberg: Metall, 26(1972), 1026.

(16) G. F. Bastin, F. J. J. van Loo and G. D. Rieck: Z. Metallk., 67(1976), 694.

(17) G. F. Bastin, F. J. J. van Loo and G. D. Rieck: Z. Metallk., 68(1977), 359.

(18) T. B. Massalski: Binary Alloy Phase Diagrams, vol. 1, American Society for Metals, Ohio, (1986), 553.

(19) W. Oelsen: Arch. Eisenhüttenwes., 51(1980), 457. 